Mila Dragojević

Sewanee: University of the South (USA)

Department of Politics
УДК: 342.842:328.122 (497.11)

Ориіинални научни рад

Примљен: 1. 3. 2013.

\title{
Andy Konitzer
}

University of Pittsburgh (USA)

Center for Russian and East European Studies

\section{THE FORENSICS OF PATRONAGE: IDENTIFYING THE LINKAGE BETWEEN PARTIES AND PUBLIC SECTOR EMPLOYMENT IN SERBIA}

While interest in political patronage continues to grow within popular and elite discourses and in academic circles, researchers still face daunting measurement challenges. Focusing on the case of Serbia, we propose a possible solution to the measurement challenge by examining the association between the size of local coalitions and employment in public enterprises in 165+ municipalities in Serbia. Using municipal-level public employment data from 2007 to 2009 and local election and coalition data from 2004 and 2008, this study identifies a relationship between the level of public employment and local government coalition size and composition in the aftermath of the 2008 local elections. The results not only provide support for popular and elite discourses about patronage in Serbia, but they also serve as a pilot test for a methodology that can be applied to other cases.

Key Words: party patronage, coalitions, elections, public enterprises, employment, Serbia

\section{Introduction}

During the 2012 Serbian Parliamentary and Presidential election campaigns, political parties, regardless of their respective attitudes towards the role of the state in the economy, focused heavily on the issue of "departicization" - a catchphrase for eliminating the practice of filling positions in public enterprises according to party membership. In a visit to a factory in the Serbian town of Velika Plana, Tomislav Nikolic, the leader of the strongest opposition party, the Serbian Progressive Party (SNS, Srpska napredna stranka), stated that party and family ties should not figure in business transactions and that all enterprises in Serbia should follow the given factory's example of how privatization should be carried out. ${ }^{1}$ Former Assistant Minister

\footnotetext{
1 "Nema posla preko stranke" ["There should be no employment through a political party"], Večernje Novosti, 22.03.2012, p.3.
} 
of Education, Srbijanka Turajlić acknowledged that the practice was well entrenched in the country's political system: "Worst of all is that our politicians and party representatives openly speak about positions in public enterprises and institutions as political spoils...For them, political spoils include everything that is not in private ownership, from schools to health clinics to public enterprises." ${ }^{2}$ The turmoil over party patronage was perhaps best manifested in an initiative undertaken by the national newspaper Blic calling on parties to sign a pledge to eliminate party patronage after the upcoming elections. By the end of March of 2012, all major parties had signed the document. ${ }^{3}$ Clearly the issue of party patronage is playing an increasingly salient role in the Serbian public discourse and has established itself as a popular gambit among Serbia's key political actors.

However, while mass media, political actors and anecdotal evidence streaming through familial and social networks suggests the pervasive nature of particization in the public sector, there have been no known efforts to rigorously assess the extent and nature of Serbian party patronage beyond directorships and boards of public enterprises. ${ }^{4}$ As the literature on issue framing and public opinion formation tells us, media and elite discourses are not always true to the reality of issues in question (Hetherington, 1996; Schneider and Jacoby, 2005; Zaller, 1992). In the case of Serbia, elites in both the government and opposition have reasons to misrepresent the extent and nature of patronage in the system. Media outlets may also be prone to misrepresent the issue because they carry the messages of elites, are politically aligned, or have a commercial interest in presenting sensational accounts of a sensitive topic.

With this in mind, the purpose of this paper is to begin addressing the lack of rigorous empirical research on Serbian party patronage. In order to do so we examine subnational covariance between changes in local government coalitions and changes in local public enterprise employment and explore the extent to which public sector jobs are linked to party patronage. Based on municipal-level public employment data from the Agency for Business Registry (APR, Agencija za privredne registre) for the period from 2007 through 2009, as well as local election and coalition data for 2004 and 2008, we find substantial empirical support for the linkage between party membership and employment in public enterprises. The level of public employment in 2009 was greater in municipalities where more sizeable coalitions formed following the

2 "Partije su postale agencije za zapošljavanje i bizniz" ["Parties became employment and business agencies"], Blic, 25.01.2012, p.4.

${ }^{3}$ Ivana Mastilović Jasnić, "Pet stranaka potpisalo," [“Five parties have signed”] Blic 28 March 2012; Ivana Mastilović Jasnić, "I Dačić ce staviti potpis," [“And Dačić will sign”] 30 March 2012; Željka Jevtić and Marija Maleš, "Inicijativu potpisao i Dačić," ["Dačić also signed the initiative"] 31 March 2012.

${ }^{4}$ Examples of studies which focus on boards of directors and directorships include (Arsić and Vasiljević, 2007; Milosavljević, 2000; Pešić, 2012). 
local elections in 2008, even when we controlled for the level of economic development. Findings for models testing the relationship between changes in coalition composition and employment volatility were more ambivalent but still suggestive of a relationship where employment falls immediately following the change in the composition of coalition governments (consistent with the firing of supporters of previous governing parties), but rises in the year following (consistent with the hiring of supporters of the new governing parties). Overall, our approach draws out the linkage between the nature of coalitions and public sector employment in Serbia, confirms certain hypotheses about the behavior of Serbian political parties, and also provides a test for a new method of assessing patronage which can be applied to other countries for broader cross-national analyses.

\section{Conceptualizing and Theorizing Party Patronage}

We begin by defining the concept of patronage. Kopecky and Scherlis define patronage as "the power of the party to appoint people to position in public and semipublic life, considering patronage to be the range of positions so distributed" (Kopecky and Scherlis, 2008: 356). Examples of such positions include "posts in the civil service, public sector companies and their governing boards, universities, advisory committees and commissions, quangos and regulatory bodies" (Kopecky and Scherlis, 2008: 356). This and similar definitions contain a number of noteworthy implications. First, the relationship between politicians and voters is distinct from the programmatic redistributive policies of political parties, which qualify as public goods since they do not exclude particular classes of beneficiaries (Stokes, 2011: 605). Second, patron client relationship is inherently asymmetrical. Patrons, who command both political and economic power, offer material benefits to clients in exchange for their political support (Scott, 1972: 92; Lemarchand, 1972: 69).

Furthermore, in defining party patronage, one must also emphasize the key characteristics of contingency, predictability, and monitoring (Kitschelt and Wilkinson, 2007: 9-19). First, unlike the programmatic appeals to voters in exchange for votes, this is a "contingent direct exchange" because the "politicians target a range of benefits only to individuals or identifiable small groups who have already delivered or who promise to deliver their electoral support to their partisan benefactor" while the voters support only those who promise to deliver a particular benefit (Kitschelt and Wilkinson, 2007: 10). Second, politicians need to be able to predict with confidence that voters who received the benefits will support them (Kitschelt and Wilkinson, 2007: 12). Third, parties monitor supporters to ensure that those who received benefits do not change sides (Kitschelt and Wilkinson, 2007: 14-19). While it may be more difficult to monitor whether the recipients actually voted for the party from which they received benefits, it is easier to do so in situations when individual citizens receive private 
goods, such as in the situations examined in this study when public sector jobs are exchanged for party membership.

Although not the main focus of this essay, a brief review of the literature examining causes of patronage is warranted. The roots of political patronage have been found in structural factors such as lower levels of economic development and poverty (Kitschelt, 2000; Kitschelt and Wilkinson, 2007; Lemarchand, 1972; Scott, 1972; Calvo and Murillo, 2004; Stokes, 2011; Wantchekon, 2003; Weitz-Shapiro, 2012), historical legacies such as the close state-society linkages in post-communist states (Kopecky and Spirova, 2011; Sehring, 2009: 76) and in the timing and nature of political party system development as well as the sequencing of the creation of party systems and professional bureaucracies (O'Dwyer, 2004; Shefter, 1994). While most studies have focused on patronage as being endemic to less developed countries, a growing body of work has examined its continued presence in modern Europe and Asia and its rise and persistence in the former-communist countries of Eastern Europe and the former Soviet Union (Kopecky, Mair and Spirova, 2012; Kopecky and Spirova, 2011; O'Dwyer, 2006).

Turning to the main focus of this essay, an ongoing challenge for all studies of patronage is the issue of measurement. As stated previously, patronage is a phenomenon that few political actors or parties would prefer to document except in the context of making short-term gains against political rivals. Students of patronage practices are thus forced to use proxies or other methodological compromises in order to identify and assess their topic of interest. One such comprise is to use national-level aggregate numbers of employees or national-level expenditures on payrolls or projects as an indication of higher levels of patronage (Gordin, 2002; O'Dwyer, 2004). Such studies are subject to criticism regarding the validity of measures (aggregate payroll and employment measures could vary for any number of reasons other than patronage) and the small-N problem inherent in treating a small number of states as a single unit of analysis. Another approach is represented by studies using interviews and analysis of primary sources to assess the nature and extent of patronage in a country (Berman, 1998; Fox, 1994; Kopecky and Scherlis, 2008; Piattoni, 2001). These studies, in turn, are subject to well-worn criticism regarding the reliability of sources, measurement and the difficulty of assessing qualitative evidence across different political and cultural milieus.

More recently, studies of patronage have tried to overcome these weaknesses by moving the analysis to a micro-level with sub-national comparisons (Calvo and Murillo, 2004; Eisenstadt, 2003; Cammett and Issar, 2010; Weitz-Shapiro, 2012), or using other innovative approaches, such as field experiments (Wantchekon, 2003), to study patronage. The strengths of these approaches are twofold. First, they rely on quantitative data, which, while certainly not entirely accurate, is less subject to the multiple 
biases inherent in interviews and primary source data. When combined with interview and primary source data, a well-informed quantitative analysis provides a very convincing assessment of the reality of patronage in a given polity. Second, by shifting to the subnational level, researchers gain significantly more cases, and likely variance, which helps resolve the "many variables, few cases" problem of single or small-N case studies (King, Keohane and Verba, 1994). Recognizing the benefits of this approach, our study continues in this vein by drawing on county-level (opštine) governance, public enterprise and socio-economic data.

\section{Talking about Patronage in Post-2000 Serbia}

As previously stated, party patronage and public sector employment plays a salient role in Serbia's elite discourse. The trend of greater public concern for curbing party patronage was evident in the results of the search of the term partijsko zapošljavanje (i.e. employment in public enterprises based on party membership) in the major newspapers in Serbia, including Politika, Večernje Novosti, Dnevnik, Danas, Blic, and others, from January 2003 through April 2012. Between 2003 and 2008 the term only appeared once. After 2008 the term became more popular being mentioned five times in 2009, three times in 2010 and again five times in 2011. Tellingly, in only the first four months of 2012, the term was mentioned thirteen times, usually in the context of various parties' campaign promises.

It is now widely accepted amongst observers of Serbian politics that party control over public enterprises at both the republican and local levels is an important aspect of post-election coalition negotiations (Orlović, 2008: 553-66; Pavlović and Antonić, 2007; Pešić, 2012: 196-203). On the national level the outcome of these negotiations determines control over 14 public enterprises, which employ 89,521 employees (as of December 2011). Observers of electoral and coalition politics in Serbia frequently cite bargaining over control of these key enterprises as one of the main factors contributing to the extended coalition negotiations (and resulting political inactivity) that has marked post-2000 parliamentary elections (Orlović, 2008: 548-57; Pešić, 2012: 196-203). This dynamic is reproduced on a smaller scale in each of Serbia's $165+$ municipalities that are home to the country's remaining 400-500 public enterprises. For example, in the municipality of Novi Sad, when the governing party in 2004 became the SRS (Serbian Radical Party, Srpska radikalna stranka), 24 members of the parliament in the coalition under the leadership of the SRS from the total of 42 received functions of directors, members of the board of directors, and other leading functions of public enterprises (Pešić, 2012: 202). During the first year of the SRS's government, 965 members of the SRS obtained employment in public enterprises, while the previous governing coalition that was led by the DS (Democratic 
Party, Demokratska stranka) employed 654 party members in public enterprises (Pešić, 2012: 202).

What is evident from an overview of media reports and the above-cited research is that the mass political (as opposed to elite) expression of patronage politics in Serbian elite and popular discourse involves an exchange of party membership for employment in public enterprises. In other words, the discourse holds that membership in parties controlling public enterprises is now a prerequisite for employment in these enterprises. This is a common theme in nearly any discussion of the particization of public enterprises, and anecdotally, seems to be one of the most frequently encountered narratives in informal discussions of party patronage in different social settings.

However, as the extensive literature on elite discourse, public opinion and issue framing tells us, the salience of a particular issue is not necessarily indicative of the extent or nature of the problem in society (Hetherington, 1996; Schneider and Jacoby, 2005; Zaller, 1992). More specifically for our purposes, the coincidence of increases in elite rhetoric about party-based employment with electoral contests raises doubts as to whether party-based hiring is indeed as prevalent as this discourse claims or whether this discourse is simply a useful political gambit for opposition parties hoping to capitalize on a consistently disgruntled and distrustful electorate. Unfortunately, the growing concern within elite discourses about the expansion of the state sector and the growing role of political parties in public sector decisions has not been paralleled by efforts to measure and rigorously analyze the phenomena. Existing studies either rely on conjecture based on evidence of rising public employment rolls or focus exclusively on the composition of governing boards of various state enterprises (Arsić and Vasiljević, 2007; Milosavljević, 2000; Pešić, 2012).

Thus, our purpose is to develop a means to test hypotheses about the relationship between political parties and public sector employment. Since popular sentiment in Serbia is that parties are gatekeepers for public sector employment then by extension, one would expect that employment patterns in the public sector would vary in some manner following a change in the composition or size of governments. In a case where the number of parties remained the same, but the actual parties in the ruling coalition changed, we would expect to see supporters of the losing party replaced by supporters of the winning party. In instances where the ruling coalition changed in terms of size (here, the number of parties in the government) we would expect to see an increase in the number of employees in public enterprises (more parties mean more supporters to award.)

However, as previously indicated, one cannot validly test popular sentiments of this type by treating the country in question as a single case. With these points in mind, we join the above-mentioned researchers who use subnational data as a means to both disaggregate the data and increase the number of cases (Calvo and Murillo, 2004; 
Eisenstadt, 2003; Cammett and Issar, 2010; Weitz-Shapiro, 2012). By focusing on Serbia's $165+$ localities, we expand our number of cases sufficiently to employ multivariate regression analyses, shift the level of analysis closer to the individual interactions that are the domain of patronage practices, and control for various historical legacies and cultural factors. While such an approach does not fully resolve the measurement issue, it offers a distinct advantage in terms of the validity of measures and our confidence in our results.

Having moved to the level of opštine we apply the same logic to the level of local governance and local public enterprises. Hence, if the popular sentiment holds, then we should see changes in the nature and size of public sector employment depending upon the size and composition of the local government. All other factors held equal, local government coalitions featuring more parties will likely correspond to higher levels of local public enterprise employment since these parties will have more supporters to award with public sector employment. Furthermore, if the number of parties remained roughly the same, but new major political parties replaced old ones we should witness some volatility (increase or decrease beyond the average) as old party supporters are replaced by new ones.

To put this in terms of working hypotheses, the previous considerations can be rephrased in the following way:

H1: Localities with larger (in the sense of more participating parties) coalition governments will have larger numbers of employees in public enterprises

H2: Localities where coalition size increased during the most recent elections will have larger numbers of employees in public enterprises

H3: Localities where the composition of the ruling coalition changed should experience higher levels of employment (increase or decrease) volatility than ones where the composition of the ruling coalition remained largely the same.

Aside from the impact of changes in the ruling coalition, we also anticipate that public enterprise employment will also vary by the level of economic development in the region and by population size. For the former, in keeping with the extensive literature, we expect poorer regions to exhibit higher numbers of public enterprise employment. Logically, we also expect higher numbers of public sector employees in regions with larger populations.

\section{Data and Methodology}

As indicated above, we define party patronage in the Serbian case as the exchange of public employment in return for party membership (Stokes, 2011: 605). To cast this in more social scientific terminology, the dependent variable in our analysis thus becomes a measure of total employment during a given year in public enterprises located on the territory of each of Serbia's 165+ opština. Public employment 
data at this level for the period from 2007 through 2009 is collected by the APR from annual reports by public enterprises. ${ }^{5}$ It should be noted that some public enterprises report these figures to the Treasury Office in the Ministry of Finance and Business instead of the APR. ${ }^{6}$ However, the overwhelming majority of public enterprises report this data to APR and the decision to report to either APR or the Ministry of Finance is taken in an arbitrary manner. ${ }^{7}$ Therefore we are confident that this provides the best available representation of public enterprise employment levels.

Figure 1. Registered Public Enterprises 2000-2010 ${ }^{8}$

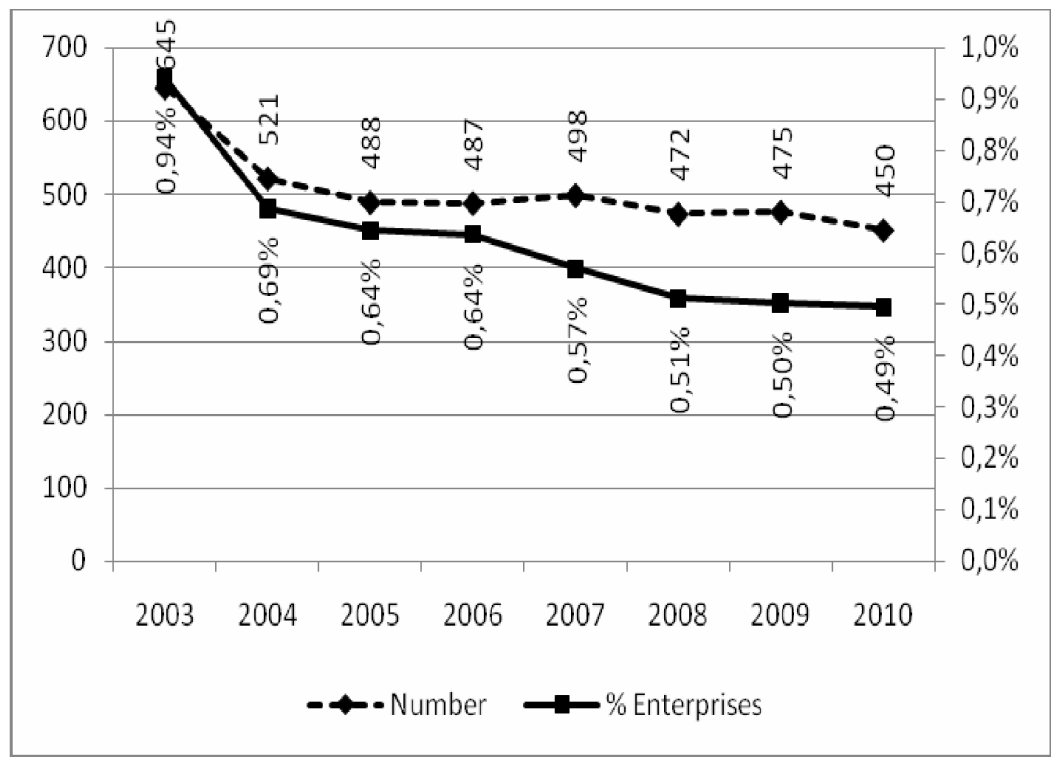

Having settled on this particular measure, we can then present both more general and more nuanced pictures of the state of public enterprises in Serbia. While

5 The Article 32 of the Law on Accounting and Revision requires public enterprises to file their business reports, including employment levels and profitability, with the APR (See Zakon o računovodstvu i reviziji, Službeni glasnik $R S$, No. 46/06 and 111/09).

6 The Law on the Budget System requires some public enterprises to file their annual reports with the Treasury (See Zakon o budžetskom sistemu, Službeni glasnik RS, No. 54/2009, 73/2010 (Articles 42 -44) and 101/2010.

${ }^{7}$ Based on the interview with two representatives of the Ministry of Finance, Dijana Ilić-Zogović and Leposava Popović.

${ }^{8}$ Source: APR (Agencija za privredne registre, Agency for Business Registry) 
the 2012 campaign rhetoric and surrounding media discourse suggests that Serbia's public sector is a steadily expanding and malignant component of Serbia's economy, an overview of Republic-level data trends suggests a more complex picture. Serbia seems to be ripe ground for party patronage of this type, but is the problem really growing? According to APR data, between 2003 and 2010, the number of registered public enterprises declined on a nearly annual basis from a peak 645 enterprises in 2003 to a minimum of 450 enterprises in 2010. In terms of the proportion of total enterprises registered in Serbia, public enterprises declined from a high of $0.94 \%$ in 2003 to a low of $0.49 \%$ in 2010 .

However, while the overall number of enterprises and these enterprises' share of the total number of all types of enterprises in the country is not increasing, the impact of the remaining enterprises on the aspect of the economy which citizens experience most directly - i.e. employment - has grown. Thus, the importance of public enterprises for the Serbian economy, and for our study, is more clearly demonstrated by the proportion of the total workforce employed in public enterprises. Table 1 presents data on total numbers of workers employed in public enterprises and workers employed in public enterprises as a percentage of total employment. ${ }^{9}$ As evidenced in Figure 2, employment in public enterprises as a share of total employment had steadily fallen from 2003 to 2008. However, coinciding with the global economic crisis, that share rose by one percentage point from 2009-2010 - a rather significant increase considering the range of change (a little under $6 \%$ ) over the period under examination. Thus, while the number of public enterprises and their share of the total number are perhaps declining, the public sector is an increasingly important factor in the labor market.

Shifting to the local level, which is the main grounds for our exploration, APR statistics allow us to paint of clearer picture of the variation of employment across Serbia's opštine. Based on the records of public enterprises of APR, which are included in the analyses of this paper, the average number of employees in public enterprises was 182 in 2008 and 181 in 2009 (Table 1).

\footnotetext{
${ }^{9}$ One should also note the significant ripple effect that such a proportion of the total work force can impose on the entire economy. As one example, during the extended coalition negotiations that occurred following the 2008 parliamentary elections, public enterprises in the municipality of Kikinda significantly scaled back their activities and spending. This had a marked impact on local suppliers and service industries like restaurants and retailers, which in turn affected small tradespeople and farmers.
} 
Figure 2. Employment and Employment as Percentage of Total ${ }^{10}$

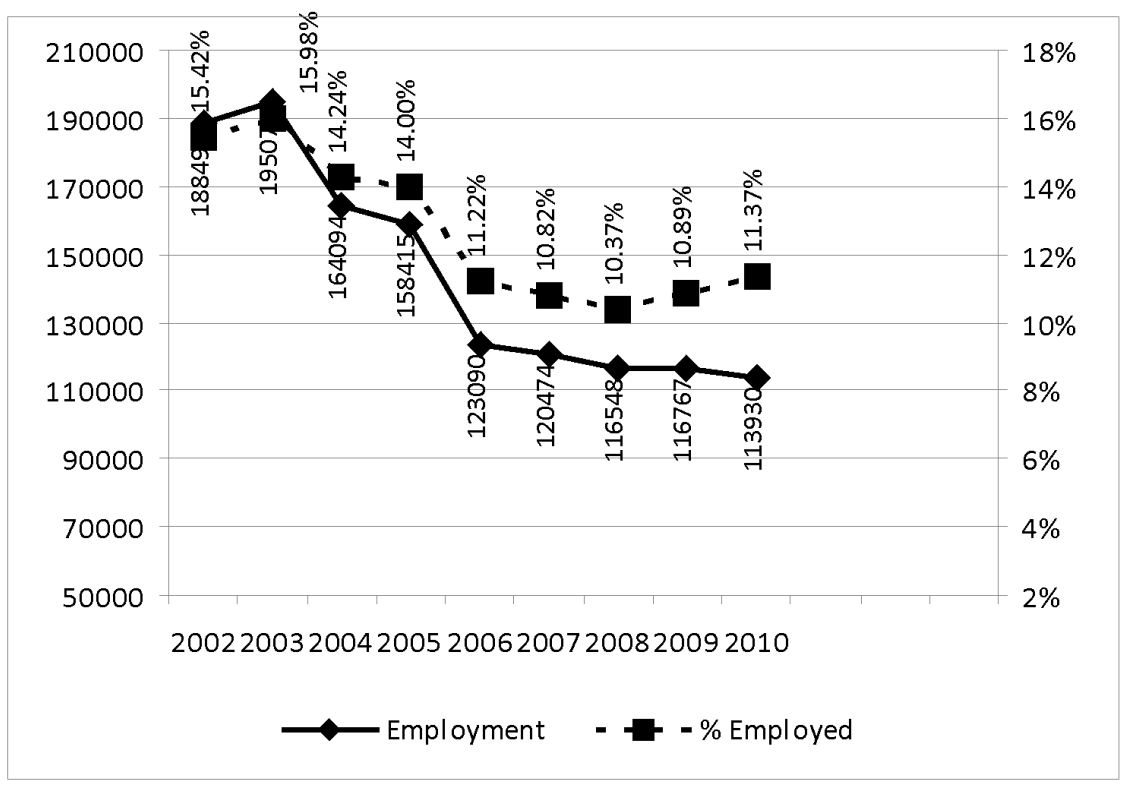

Table 1. Descriptive Statistics of Employment in Public Enterprises and Population

\begin{tabular}{|l|c|c|c|c|c|}
\hline \multicolumn{1}{|c|}{ Variables } & Observations & Mean & Std. Dev. & Min. & Max. \\
\hline $\begin{array}{l}\text { Number of } \\
\text { employees in public } \\
\text { enterprises in 2008 }\end{array}$ & 141 & 182 & 198 & 0 & 795 \\
$\begin{array}{l}\text { Number of } \\
\text { employees in public } \\
\text { enterprises in 2009 }\end{array}$ & 139 & 181 & 200 & 0 & 822 \\
Total population & 167 & 55836 & 127490 & 2563 & 1576124 \\
\hline
\end{tabular}

The maximum number of employees was 795 in 2008 and 822 in 2009. Considering that the average size of municipality is only 55,835 people, the employment in public enterprises constitutes a significant proportion of the employment in Serbia.

10 Source: APR 
Moving to our dependent variable, Coalition Size is a count of the number of political parties participating in the local government formed following the 2004 and 2008 local government elections. The local election data for 2004 and 2008 comes from the Institute for Statistics of the Republic of Serbia (RZS, Republickki zavod za statistiku) and the Center for Free Elections and Democracy (CeSID, Centar za slobodne izbore i demokratiju). ${ }^{11}$ The average coalition on the local level following the 2008 elections included five parties (Table 2). The smallest coalition consisted of one party and the largest of nineteen. If we take out the outlier Bela Crkva municipality, the largest coalition includes twelve parties.

Table 2. The Size of Coalition Governments in 2008

\begin{tabular}{|l|c|l|l|}
\hline Descriptive Statistics & & $\begin{array}{c}\text { "Largest" } \\
\text { Governments (\#) }\end{array}$ & $\begin{array}{c}\text { "Smallest" } \\
\text { Governments (\#) }\end{array}$ \\
\hline Median \# Parties & 6 & Bela Crkva (19) & Doljevac (1) \\
Mean \# Parties & 5.37 & Zaječar (12) & Vračar (2) \\
St. Dev. & 2.49 & Novi Sad (10) & Sopot (2) \\
Max \# Parties & 19 & Pirot (10) & Kovačica (2) \\
Minimum \# Parties & 1 & Niška Banja (10) & Bač (2) \\
& & Smederovo (10) & Bački Petrovac (2) \\
\hline
\end{tabular}

The Coalition Size $\Delta$ represents the change in the number of parties participating in local government coalitions between the 2004 and 2008 elections. It is derived by simply subtracting the Coalition Size variable from the 2008 elections from the Coalition Size variable from the 2004 elections. The average change in the size of the coalition was one party. The minimum change was a decrease in ten parties and the maximum change was an increase in fifteen parties.

Finally, the Coalition Composition $\Delta$ measures whether the parties in the local coalition changed after the 2008 elections even in the cases where the size of the local coalition remained the same (Table 3 ). The change in the composition of local coalitions is an ordinal variable ranging from 0 to 6 , where 0 represents no change in the coalition partners, 1 represents a change of three or fewer new and small parties, 2 represents a change of more than three new and small parties, 3 represents the change of at least one new large party, 4 represents the change of two major parties, 5 represents the change of three major parties, and 6 represents a change that results in a completely new set of parties.

\footnotetext{
${ }^{11}$ See CeSID Directory of Local Self Government website (http://direktorijum.cesid.org/).
} 
Mila Dragojević, Andy Konitzer, The Forensics of Patronage: Identifying the Linkage between...

Table 3. The Change in the Composition of Coalition Governments from 2004 to 2008

\begin{tabular}{|l|c|}
\hline \multicolumn{2}{|c|}{ Descriptive Statistics } \\
\hline Mean & 4.64 \\
\hline St. Dev. & 0.98 \\
\hline Number of counties coded & 159 \\
\hline Counties with maximum change in coalition composition $(6)$ & 16 \\
\hline Counties with no change in coalition composition $(0)$ & $(10 \%)$ \\
\hline
\end{tabular}

In only one county, Topola, there was no change in the local coalition following 2008 elections, while in 10 percent of 159 counties that were coded, or 16 counties, the change in the composition of local coalitions resulted in a complete set of new parties (Table 3). Change in two to three major parties was the average type of change in the composition of local coalitions (Table 3).

Our measure of the level of local economic development is drawn from APR data. APR divides Serbia's opštine into four categories of development based upon the per capita gross local product as a percentage of Republican average. First category localities are those with a per capita gross local product that is above the Republican average. Second category localities feature per capita gross local products, which are between $80 \%$ and $100 \%$ of the Republican average. Third category localities are those whose per capita gross local products are from $60 \%-80 \%$ of the Republican average and Fourth category localities are those with per capita gross local products that are below $60 \%$ of the Republican average. The average level of economic development was the category three. This study, thus, uses principally the data from the APR on economic development and the number of employees in local public enterprises from 2007 to 2009, as well as the data from the RZS and CeSID on the coalitions that formed following the 2004 and 2008 local elections.

\section{Linkages Between Local Coalitions and Employment in Public Enterprises}

The results of statistical analyses show strong support for the first hypothesis and tentative support for the second and third hypotheses. Localities with coalition governments consisting of more participating parties have larger numbers of employees in public enterprises both in 2008 and in 2009. Localities where coalition size increased following the 2008 elections have larger numbers of employees in public enterprises in 2009. Our results also provide tentative evidence of a pattern of personnel changes following a change in the composition of government that is consistent with party-mem- 
bership based patronage. Employment levels declined during the year of the election in localities where there was the highest turnover of parties across the outgoing in incoming governments. Furthermore, employment levels increased during the year following elections in localities where there was the highest turnover of parties. This suggests that the inclusion of new parties in incoming coalition governments result in an exodus (either voluntarily or through firings) of old party supporters from public enterprises, followed by the hiring of new party supporters in the year following the election.

Beginning with the first two hypotheses tests, in Models 1 and 2 in Table 4, the dependent variable is the number of employees in public enterprises in 2008, and in Models 3 and 4, it is the number of employees in public enterprises in 2009. Models 1 and 3 test the first hypothesis (effect of new coalition size) and Models 2 and 4 test the second hypothesis (effect of change in coalition size). In addition to the key explanatory variables, such as the local coalition size in Models 1 and 3, and change in the local coalition size in Models 2 and 4, we also include the following controls in the first four models: local economic development, population size, and whether or not the locality in question is located in the Autonomous District of Vojvodina. ${ }^{12}$ The variable Vojvodina controls for historical, economic, and cultural factors, which are specific to the region of Vojvodina and may influence informal institutions, such as patronage practices. The rationale for using the population size is that larger localities may have more employees in public enterprises, and if despite including this variable, we still find a significant and positive relationship between coalition size and public employment, we can conclude that it is not merely because the locality is demographically larger.

Our analysis in all models excludes Belgrade because we lack the data on the number of employees in public enterprises in 2009. As indicated in Table 2, Bela Crkva stands out as an outlier in terms of coalition size for the 2008 elections. Subsequent analyses indicated that the exceptionally large number of parties in Bela Crkva's government made this a statistically influential case. ${ }^{13}$ Therefore, Bela Crkva was dropped from the analyses in all models.

${ }^{12}$ A Vojvodina dummy was added after a model including measures of the ethnic makeup of municipalities returned strong results for the Hungarian minority. We found that a dummy indicating whether a municipality was located in Vojvodina provided even greater explanatory power than the highly correlated measure of the percentage of Hungarians living in a region. There are a number of potential reasons why the linkage between coalition size and public sector employment might be weaker in the Autonomous District of Vojvodina. We will investigate these in future stages of our research.

${ }^{13}$ Influential cases are ones whose values on specific variables are such that they have an inordinate impact on regression results. 
Mila Dragojević, Andy Konitzer, The Forensics of Patronage: Identifying the Linkage between...

\section{Coalition Size}

We now turn to the interpretation of our results. With regard to the first hypothesis, which posits a link between coalition size and local public enterprise employment, the results indicate a statistically significant and positive relationship between coalition size and employment in local public enterprises (Table 4, Models 1 and 3). Controlling for economic development, population size and regional factors, for every additional party in a local coalition local enterprise employment increases by 13 employees in 2008 and 14 in 2009.

The second hypothesis positing a linkage between the magnitude of change in coalition size and change in local government employment received tentative support (Table 4, Models 2 and 4). A one-party increase in the number of parties in specific municipality's ruling coalition after the 2008 election predicts an increase in employment numbers in public enterprises of 9 in 2009. However, the marginal level of statistical significance $(\mathrm{p} .=0.09)$ raises some questions about the strength and validity of this relationship.

Table 4. Local Employment in Public Enterprises and Local Coalitions

\begin{tabular}{|c|c|c|c|c|c|c|c|c|}
\hline \multirow{3}{*}{ Coalition Size } & \multirow{2}{*}{\multicolumn{2}{|c|}{$\begin{array}{c}\begin{array}{c}\text { Model 1 } \\
\text { Employ08 }\end{array} \\
\text { Coef. }\end{array}$}} & \multirow{2}{*}{\multicolumn{2}{|c|}{$\begin{array}{c}\begin{array}{c}\text { Model 2 } \\
\text { Employ08 }\end{array} \\
\text { Coef. }\end{array}$}} & \multirow{2}{*}{\multicolumn{2}{|c|}{$\begin{array}{c}\begin{array}{c}\text { Model 3 } \\
\text { Employ09 }\end{array} \\
\text { Coef. }\end{array}$}} & \multirow{2}{*}{\multicolumn{2}{|c|}{$\begin{array}{c}\begin{array}{c}\text { Model } 4 \\
\text { Employ09 }\end{array} \\
\text { Coef. }\end{array}$}} \\
\hline & & & & & & & & \\
\hline & $\begin{array}{l}12.66 \\
(6.27)\end{array}$ & $*$ & --- & & $\begin{array}{l}13.82 \\
(6.40)\end{array}$ & $*$ & --- & \\
\hline Coalition Size $\Delta$ & --- & & $\begin{array}{c}8.27 \\
(5.40) \\
\end{array}$ & & --- & & $\begin{array}{c}9.41 \\
(5.48) \\
\end{array}$ & a \\
\hline $\begin{array}{l}\text { Coalition } \\
\text { Composition } \Delta\end{array}$ & --- & & --- & & --- & & --- & \\
\hline Development & $\begin{array}{l}-38.46 \\
(12.32)\end{array}$ & $* *$ & $\begin{array}{l}-39.36 \\
(12.38)\end{array}$ & $* *$ & $\begin{array}{l}-38.90 \\
(12.40)\end{array}$ & $* *$ & $\begin{array}{l}-39.85 \\
(12.46)\end{array}$ & $* *$ \\
\hline Population & $\begin{array}{c}0.00 \\
(0.00) \\
\end{array}$ & $* * *$ & $\begin{array}{c}0.00 \\
(0.00) \\
\end{array}$ & $* * *$ & $\begin{array}{c}0.00 \\
(0.00) \\
\end{array}$ & $* * *$ & $\begin{array}{c}0.00 \\
(0.00) \\
\end{array}$ & $* * *$ \\
\hline Vojvodina & $\begin{array}{c}-55.68 \\
(32.08) \\
\end{array}$ & a & $\begin{array}{l}-55.75 \\
(32.31) \\
\end{array}$ & a & $\begin{array}{l}-55.39 \\
(32.33) \\
\end{array}$ & a & $\begin{array}{r}-55.55 \\
(32.56) \\
\end{array}$ & $\mathrm{a}$ \\
\hline Adjusted $\mathrm{R}^{2}$ & 0.41 & & 0.40 & & 0.41 & & 0.40 & \\
\hline $\mathrm{N}$ & 135 & & 135 & & 134 & & 134 & \\
\hline
\end{tabular}

Note: All models are ordinary least squares (OLS) regressions. Coefficients are listed in the cells with corresponding standard errors in the parentheses.

$* * * \mathrm{p}<.001 * * \mathrm{p}<.01,{ }^{*} \mathrm{p}<.05,{ }^{\mathrm{a}} \mathrm{p}=0.09$.

Findings for the control variables also present interesting results for future consideration. Models 1-4 show that, contrary to much of the literature on patronage, poorer municipalities, or those with a larger value of the APR index, have 
lower levels of public employment. This trend could be explained by the availability of resources meaning that public sector jobs are more plentiful in those localities that have larger budgets. While this requires further examination, such a finding seems to raise another challenge to the traditional linkage between poverty and patronage. Perhaps the presence of resources to fund public sector jobs is sufficient incentive for parties to pursue patronage regardless of the overall level of economic development in a particular case. Finally, with all other factors taken into account, counties in Vojvodina appear to have lower levels of public employment compared to counties in the rest of Serbia, as evident in Models 1-4. Possible sources of this interesting regional variation will require additional research and will be explored in the extensions of this study.

\section{Coalition Composition}

At this stage our findings suggest a link between coalition size and the number of workers employed in public enterprises. Our next question focuses on whether changes in the composition of coalitions have an appreciable effect on turnover in public enterprises immediately following elections. In Models 5 and 6 in Table 5, the dependent variable is the percent change in employment from 2007 to 2008 and from 2008 to 2009 , respectively. Both models test the third hypothesis positing a relationship between the change in the composition of the local coalition following the 2008 elections and the year-to-year volatility in the level of employment in public enterprises. In both models we include a control for the percent change in the number of public enterprises in the region over the year in question. If a significant relationship between change in public employment levels and the change in the composition of coalitions is still evident, we will be able to conclude that the change in employment levels did not occur just because of a change in the number of public enterprises operating in the region.

As indicated earlier, the results of the analysis in Model 5 provide tentative support for the third hypothesis (Table 5). In Model 5, the direction of the change in public employment in 2008 following the elections is negative in those municipalities where the composition of coalitions changed the most. These results are consistent with our initial hypothesis that there is a link between the composition of local coalitions and the post-electoral volatility in employment levels in public enterprises. However, with a p-value of .27 the relationship falls short of standard criteria for statistical significance. In Model 6, the public enterprise employment levels in 2009 increased, when compared to the employment numbers in 2008, in those municipalities where the composition of coalitions changed the most following the 2008 elections. 
Mila Dragojević, Andy Konitzer, The Forensics of Patronage: Identifying the Linkage between...

Table 5. Volatility of Local Employment in Public Enterprises and Coalition Composition Change

\begin{tabular}{|l|c|c|c|c|}
\hline & \multicolumn{2}{|c|}{$\begin{array}{c}\text { Model 5 } \\
\text { Employ07-08 }\end{array}$} & \multicolumn{2}{c|}{$\begin{array}{c}\text { Model 6 } \\
\text { Employ08-09 }\end{array}$} \\
\hline & \multicolumn{2}{|c|}{ Coef. } & \multicolumn{2}{|c|}{ Coef. } \\
\hline Change in Coalition Composition & $\begin{array}{c}-0.02 \\
(0.02)\end{array}$ & $\begin{array}{c}0.03 \\
(0.01)\end{array}$ & $*$ \\
\hline \% Change in Public Enterprises 07-08 & $\begin{array}{c}0.32 \\
(0.04)\end{array}$ & $* * *$ & --- & \\
\hline \% Change in Public Enterprises 08-09 & --- & & $\begin{array}{c}0.49 \\
(0.06)\end{array}$ & $* * *$ \\
\hline & & & & \\
\hline Adjusted $\mathrm{R}^{2}$ & 0.33 & & 0.34 & \\
\hline $\mathrm{N}$ & 129 & & 128 & \\
\hline
\end{tabular}

Note: All models are ordinary least squares (OLS) regressions. Coefficients are listed in the cells with corresponding standard errors in the parentheses. Preševo and Senta dropped from both analysis as influential cases.

$* * * \mathrm{p}<.001 * * \mathrm{p}<.01, * \mathrm{p}<.05$.

The tentative nature of these findings warrants further comment. Explanations for the low p-value in Model 5 include issues regarding the method applied, the context of the 2008 local elections, and the simple challenge of accounting for employment volatility. With regard to the method, a more precise measure of change in coalition composition or the inclusion of other relevant controls might yield a clearer relationship. We will continue to develop this part of the analysis in future work. Regarding the electoral context, it should be noted that the split within the Serbian Radical Party and the subsequent rise of the Serbian Progressive Party following the 2008 local elections created considerable delay and fluctuations in the formation of local government coalitions throughout the fall of 2008. Thus, the weakness of the relationship in Model 5 could be attributed to the fact that many localities did not establish stable coalition governments until late 2008 and early 2009. Delayed coalition formation would thus delay changes to employment in local public enterprises. In light of this argument we will apply a similar model in the post-2012 local election context once the data is available. Finally, we should point out that the many potential factors impacting employment volatility are likely to always yield somewhat weaker results for these models. Therefore, we feel that the existing outcomes are sufficiently encouraging to warrant continued development. Our analysis thus indicates that party patronage, defined as the exchange of public sector jobs for party membership, is a reality that exists beyond the instrumental rhetoric of elite discourses. Hence, our approach of measuring the linkage between local coalition governments and subnational public sector employment appears to provide a useful means for uncovering patronage practices. 


\section{Conclusion}

In this article we applied a new methodology to test the validity of popular and elite discourses regarding party patronage in Serbia. Our findings strongly suggest that employment in local public enterprise is positively related to the number of parties in local coalition governments and that patterns of hiring and firing are correlated with the magnitude of change in local coalition composition following elections. Thus, we can conclude that rhetoric about partijsko zapošljavanje reflects a consistent reality throughout Serbia's political system. Furthermore, the success of this initial application of our methodology to the Serbian case encourages us to apply the model to other political systems, thus contributing to a growing social science literature on party patronage.

From the policy standpoint, this exploration provides fresh evidence regarding the challenges facing the development of western-style party systems and bureaucracies within the context of the Balkans and Eastern Europe. In terms of party development, the findings do not bode well for the development of program-based party system structures. Parties in Serbia show an increasing tendency to join with parties of nearly any stripe in coalitions designed more to carve up bureaucratic spoils than to chart out new policy directions. The prospects for the development of a professional, merit based bureaucracy are equally dim: Conspicuously absent from this story is a strong role for expertise and any means to shield bureaucrats from the wrath of new political bosses.

On a final note, our findings further question the effectiveness of EU conditionality in promoting the development of stronger party systems and professionalized bureaucracies. While Serbia's membership to the EU is a distant and perhaps even dwindling prospect, strong evidence of continuing party patronage during a period when Serbia's leaders are ostensibly trying to woo European leaders suggests that certain, more immediate, payoffs are stronger than the longer terms payoff of meeting European standards. However, anecdotal and even more systematic evidence of patronage practices in recent EU members suggests that such a finding is perhaps less surprising than one might expect. 
Mila Dragojević, Andy Konitzer, The Forensics of Patronage: Identifying the Linkage between...

\section{REFERENCES}

Arsić, M., and D. Vasiljević. (2007). Restrukturiranje i privatizacija javnih preduzeća u Srbiji. Kvartalni Monitor 9: 89-99.

Berman, B. J. (1998). Ethnicity, Patronage and the African State: The Politics of Uncivil Nationalism. African Affairs 97 (388): 305-41.

Calvo, E., and M. V. Murillo. (2004). Who Delivers? Partisan Clients in the Argentine Electoral Market. American Journal of Political Science 48 (4): 742.

Cammett, M., and S. Issar. (2010). Bricks and Mortar Clientelism: Sectarianism and the Logics of Welfare Allocation in Lebanon. World Politics 62 (3).

Eisenstadt, T. A. (2003). Thinking Outside the (Ballot) Box: Informal Electoral Institutions and Mexico's Political Opening. Latin American Politics and Society 45 (1): 25-54.

Fox, J. (1994). The Difficult Transition from Clientelism to Citizenship: Lessons from Mexico. World Politics 46 (2): 151-84.

Gordin, J. P. (2002). The Political and Partisan Determinants of Patronage in Latin America 19601994: A Comparative Perspective. European Journal of Political Research 41: 513-49.

Hetherington, M. J. (1996). The Media's Role in Forming Voters' National Economic Evaluations in 1992. American Journal of Political Science 40 (2): 372-95.

King, G., R. Keohane, and S. Verba. (1994). Designing Social Inquiry: Scientific Inference in Qualitative Research. Princeton: Princeton University Press.

Kitschelt, H. (2000). Linkages between Citizens and Politicians in Democratic Polities. Comparative Political Studies 33 (6/7): 845-79.

Kitschelt, H., and S. Wilkinson, eds. (2007). Patrons, Clients and Policies: Patterns of Democratic Accountability and Political Competition. New York: Cambridge University Press.

Kopecky, P., P. Mair, and M. Spirova, eds. (2012). Party Patronage and Party Government in European Democracies. Oxford: Oxford University Press.

Kopecky, P., and G. Scherlis. (2008). Party Patronage in Contemporary Europe. European Review 16 (3): 355-71.

Kopecky, P., and M. Spirova. (2011). 'Jobs for the Boys'? Patterns of Party Patronage in Post-Communist Europe. West European Politics 34 (5): 897-921.

Lemarchand, R. (1972). Political Clientelism and Ethnicity in Tropical Africa: Competing Solidarities in Nation-Building. American Political Science Review 66 (1): 68-90.

Milosavljević, M. e. a. (2000). Kako stati na put politizaciji javnih preduzeća u Srbiji [How to Depoliticize Public Enterprises in Serbia]. Belgrade: Centar za primenjene evropske studije (CPES).

O'Dwyer, C. (2004). Runaway State Building: How Political Parties Shape States in Postcommunist Eastern Europe. World Politics 56 (4): 520-33.

---. (2006). Runaway State-Building: Patronage Politics and Democratic Development. Baltimore: Johns Hopkins University Press.

Orlović, S. (2008). Politički život Srbije: između partokratije i demokratije. Belgrade: Službeni Glasnik.

Pavlović, D., and S. Antonić. (2007). Konsolidacija demokratskih ustanova u Srbiji posle 2000. godine. Beograd: Službeni glasnik. 
Pešić, V. (2012). Divlje društvo: Kako smo stigli dovde. Belgrade: Peščanik.

Piattoni, S., ed. (2001). Clientelism, Interests, and Democratic Representation: The European Experience in Historical and Comparative Perspective. New York: Cambridge University Press.

Schneider, S., and W. Jacoby. (2005). Elite Discourse and American Public Opinion: The Case of Welfare Spending. Political Research Quarterly 58 (2): 367-79.

Scott, J. C. (1972). Patron-Client Politics and Political Change in Southeast Asia. American Political Science Review 66 (1): 91-113.

Sehring, J. (2009). Path Dependencies and Institutional Bricolage in Post-Soviet Water Governance. Water Alternatives 2 (1): 61-81.

Shefter, M. (1994). Political Parties and the State: The American Historical Experience. Princeton: Princeton University Press.

Stokes, S. C. (2011). Political Clientelism. In: C. B. a. S. C. Stokes (ed.), The Oxford Handbook of Comparative Politics New York: Oxford University Press, pp. 604-27.

Wantchekon, L. (2003). Clientelism and Voting Behavior: Evidence from a Field Experiment in Benin. World Politics 55 (3): 399-422.

Weitz-Shapiro, R. (2012). What Wins Votes: Why Some Politicians Opt Out of Clientelism. American Journal of Political Science 0 (0): 1-16.

Zaller, J. R. (1992). The Nature and Origins of Public Opinion. New York: Cambridge University Press. 
Mila Dragojević, Andy Konitzer, The Forensics of Patronage: Identifying the Linkage between...

Мила Драгојевић

Сажейак

Sewanee: University of the South (USA)

Department of Politics

Andy Konitzer

University of Pittsburgh (USA)

Center for Russian and East European Studies

\section{СУДСКО ПОКРОВИТЕЉСТВО: ИДЕНТИФИКАЦИЈА ВЕЗЕ ИЗМЕБУ ПАРТИЈА И ЈАВНОГ СЕКТОРА У СРБИЈИ}

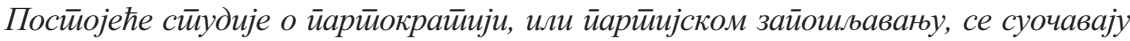
са двосиируким изазовом. Једна од йешкоћа је мерење с обзиром да владајуће елииее,

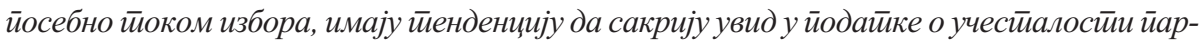
ииијской зайошьвавана, док оиозиционе сииранке имају йенденцију да увеличају обим йарйокрайије као један од ирроблема који се йрийисује владајућим сииранакама. Друіуу иррейреку имају сйудије са малим узорком јер су оіраничене малим бројем ойсервација и великим бројем йоиенцијалних чиниоца. Ова сйудија йревазилази оба йроблема йред-

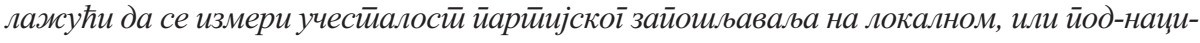
оналном нивоу, мерећи корелацију између величине локалних коалиија и зайошьввана у јавним йредузећима у 165 ойиимина у Србији. Сйайистиччка анализа йодайака о нивоу јавної зайошљаваља йо ойийинама од 2007. до 2009. и резулйайа локалних избора из 2004. и 2008. йоказује да је ниво јавної зайошььавања у 2009. био већи у оним ойийинама у којима су формиране веће коалщије након локалних избора у 2008, без обзира на ниво економскої развоја у дайој ойшитини.

Кључне речи: йарӣокраӣија, коалищие, ибори, јавна йредузећа, Србија 